\title{
GROWTH OF Litopenaeus schmitti (BURKENROAD, 1936) AND Farfantepenaeus paulensis (PEREZ-FARFANTE, 1967) SHRIMP REARED IN RECIRCULATION CULTURE SYSTEM
}

\author{
Marcelo Barbosa Henriques*, Pedro Mestre Ferreira Alves, Oscar José Sallée Barreto \\ and Marcelo Ricardo de Souza
}

Instituto de Pesca - Secretaria de Agricultura e Abastecimento do Estado de São Paulo (Av. Bartolomeu de Gusmão, 192, 11030-906 Santos, SP, Brasil)

*Corresponding author: henriquesmb@pesca.sp.gov.br

http://dx.doi.org/10.1590/S1679-87592014078806204

\begin{abstract}
A B S T R A C T
The Litopenaeus schmitti and Farfantepenaeus paulensis shrimp captured in estuaries are marketed as live bait for recreational fishing. As an alternative to shrimp extractive activities, the authors evaluated the rearing of these species in a recirculation culture system. For each species, the grow-out study was carried out in two 120-day production cycles, using 3,300 juveniles of an average length of $25 \mathrm{~mm}$ and weight of 0.9 grams in each, distributed in 12 tanks of 1,500 liters and $1.32 \mathrm{~m}^{2}$, at a population density of 208.3 shrimp per $\mathrm{m}^{2}$. The growth parameters were obtained using the von Bertalanffy model based on the length $(\mathrm{mm})$ and age (weeks) data. The adjustments were made in the $\mathrm{R}$ environment of the non-linear least-square method. The von Bertalanffy growth model showed a proper fit, with determination coefficients of 0.900 for $L$. schmitti and 0.841 for $F$. paulensis. The values of $\mathrm{L} \infty$ and $\mathrm{k}$ were 172.66 and $0.027 \mathrm{~mm}$ for $L$. schmitti and $110.13 \mathrm{~mm}$ and 0.050 for $F$. paulensis, respectively. In the current study, L. schmitti showed negative allometric growth $(\mathrm{p}=4,314 \times 10-18)$ and $F$. paulensis isometric growth $(\mathrm{p}=0.267)$. The growth of shrimp obtained in the proposed recirculation system can supply live bait for the sport fishing market.
\end{abstract}

\section{RESUMO}

Os camarões Litopenaeus schmitti e Farfantepenaeus paulensis capturados pela pesca artesanal nos estuários são comercializados como iscas vivas na pesca esportiva. Como alternativa à atividade extrativista foi avaliado o cultivo dessas espécies em sistema de recirculação de água. Para cada espécie foram realizados dois ciclos de produção de 120 dias, utilizando 3300 juvenis em cada um, com média de $25 \mathrm{~mm}$ de comprimento e 0.9 gramas em peso, dispostos em 12 tanques de $1500 \mathrm{~L}$ e $1.32 \mathrm{~m}^{2}$, na densidade de 208.3 camarões $\mathrm{m}^{2}$. Os parâmetros de crescimento foram obtidos utilizando-se o modelo de von Bertalanffy baseado nos dados de comprimento ( $\mathrm{mm}$ ) e idade (semanas). Os ajustes foram feitos no ambiente $\mathrm{R}$ utilizando o método não-linear de mínimos quadrados. O modelo de von Bertalanffy apresentou ajuste adequado, com coeficientes de determinação de 0.900 para $L$. schmitti e 0.841 para $F$. paulensis. Os valores de L $\infty$ e k foram 172.66 mm e 0.027 para $L$. schmitti e $110.13 \mathrm{~mm}$ e 0.050 para $F$. Paulensis, respectivamente. No presente estudo L. schmitti apresentou crescimento alométrico negativo $(\mathrm{p}=4.314 \times 10-18)$ e $F$. paulensis crescimento isométrico $(\mathrm{p}=0.267)$. $\mathrm{O}$ crescimento obtido dos camarões no sistema de recirculação proposto atende ao mercado de iscas vivas da pesca esportiva

Descriptors: Growth curve, Length-weight relationship, Live bait, Marine shrimp farming, Pink shrimp, White shrimp.

Descritores: Curva de crescimento, Relação comprimento-peso, Isca viva, Carcinicultura marinha, Camarão rosa, Camarão branco.

\section{INTRODUCTION}

Recreational fishing is on the increase in Brazil thus generating a market opportunity for extractive activities for small and medium-sized producers. The rapid growth of the live bait market has disrupted the supply of juvenile shrimp, leading to intensive fishing activity for them in estuaries
(BARBIERI, 2010). This disordered extraction in natural shrimp nurseries, besides leading to overfishing, is responsible for the direct progressive depletion of natural stocks, because the extraction is undertaken in both the substrates of the population, with the capture of juveniles in estuarine areas and adults in oceanic waters (VALENTINI et al., 1991). 
The penaeids are an important resource for fisheries and aquaculture worldwide, playing an important socio-economic role in the South Atlantic (BARBIERI, 2010). The decline in catches observed on the Brazilian coast in recent decades has stimulated the development of cultivation technologies as an alternative to this scenario (LOMBARDI et al., 2001; WASIELESKY et al., 2004; FÓES et al., 2011).

The production of marine shrimp in water recirculation systems, in accord with the quarantine protocol for pathogen and diseases control, seeks to mitigate both environmental and epizootic impacts, since no effluent is discharged into a body of water, thus complying with the standards of the International Organization of Epizootics - The World Organization for Animal Health (OIE).

The rapid growth of the live bait market has disrupted the supply of juvenile shrimp, causing overfishing and predatory fishing in estuaries. As an alternative means to meet this demand in Brazil, the Pacific white shrimp (Litopenaeus vannamei) has been adopted as the main live bait in recreational fishery, characterizing a direct introduction of an exotic species. Both situations are highly worrisome and may cause environmental damage.

The economic indicators used to assess the investment in water recirculation systems for the production of live bait has shown an Internal Rate of Return (IRR) of $11.74 \%$ for the trade price of US\$ 0.50 (BARROS et al., 2014).

This system follows the trend of modern shrimp farming to increase production through increased stocking density (GODDARD, 1996). In addition, the recirculation of water prevents the introduction of pathogens into the system, mitigating environmental problems and contrasting with the methods of other users of the coastal area by not discharging effluents into water bodies (DAVIS; ARNOLD, 1998).

The growth analysis of penaeids is a tool for the assessment of fishery stocks (ARREGUÍNSANCHÉZ, 1981; KNEIB; HUGGLER, 2001; PASQUIER; PÉREZ, 2007) and economic viability (ADAMS et al., 1980; WYBAN et al., 1988; TIAN et al., 1993). In aquaculture, studies have been based on the growth of zootechnical performance aimed at improving productivity (CAVALLI et al., 2008; SOUZA et al. 2009; MÁRQUEZ et al., 2012; ANAND et al., 2013).

This study sought to obtain growth parameters and analyze the weight-length relationship of white Litopenaeus schmitti and pink Farfantepenaeus paulensis shrimp cultivated in the water recirculation system for the live bait market for sporting fishing.

\section{Material and Methods}

The study was carried out during the years 2012 and 2013 in the Mariculture Laboratory of the Fisheries Institute (LabMar - IP), located in the municipality of Santos, São Paulo State (2359'23'S; $46^{\circ} 18$ '23' W). The total area of the Laboratory covers $130 \mathrm{~m}^{2}$ and contains twelve fiberglass tanks or production units (PU), with $1500 \mathrm{~L}$ of total capacity and area per unit of $1.32 \mathrm{~m}^{2}$. There are also six other fiberglass tanks of a total of $2400 \mathrm{~L}$ capacity that act as a biological filter (Fig. 1).

The water recirculation system was adjusted to a flow of 5 liters per minute, with a daily renewal rate of 2.5 times the system's total volume. The system was programmed to operate for a daily period of $10 \mathrm{~h}$ to save energy and to increase the efficiency of biological filters.

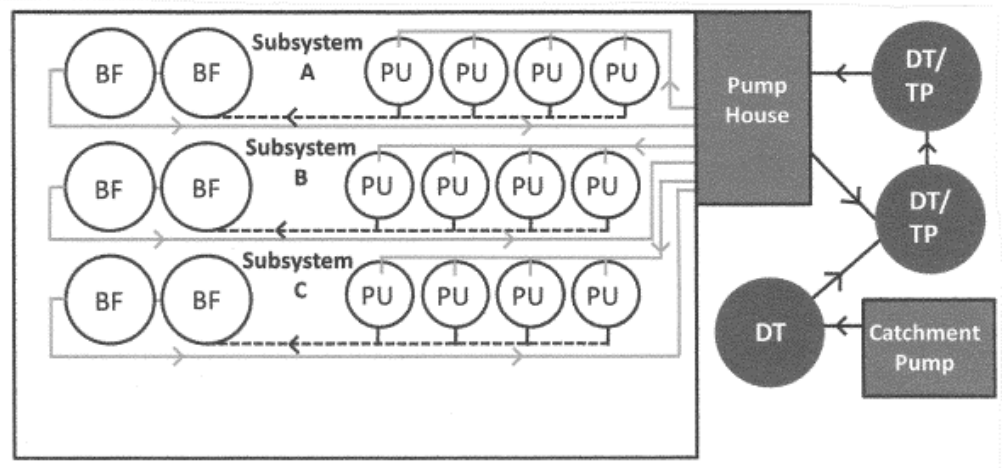

Fig. 1. Layout of water recirculation system for the production of marine shrimp. Arrows indicate the water flow direction. Black line - seawater collected and stored in decantation tanks (DT) and passage tanks (PT); Gray line - water filtered by biological filters (BF); Dashed line - waste water of production units (PU); and pump house - containing a $1 \mathrm{HP}$ motor-pump and a heat exchanger for each subsystem, a 5 HP radial compressor (blower) for the entire system, a sterilization system of ultraviolet radiation and a sand filter. 
The physicochemical parameters of the recirculation culture system were measured weekly and the data analyzed by ANOVA and the Tukey test $(P<0.05)$ to verify possible differences between the PUs and the experimental cycles.

Two production cycles (harvests) were carried out for each species with 3,300 juveniles each of Litopenaeus schmitti and Farfantepenaeus paulensis in each cycle and 275 individuals per PU, with average initial length and weight of $25 \mathrm{~mm}$ and $0.9 \mathrm{~g}$, respectively, with a population density of 208.3 shrimp per $\mathrm{m}^{2}$. The post-larvae used in the experiments were collected in the Cananéia estuary, in the coastal region of São Paulo State, Brazil.

The biometric measurements comprised the total length of the shrimp from the distal part of the rostrum to the distal part of the telson measured with a digital stainless steel caliper (precision of $0.01 \mathrm{~mm}$ ) and their weight measured on an analytical balance (precision of $0.001 \mathrm{~g}$ ).

The diet consisted of commercial feed for penaeids with $35 \%$ crude protein $(\mathrm{CP})$, corresponding to $3 \%$ of the daily biomass for each PU. The quantity of food was adjusted in accordance with the weekly biometrics and offered twice daily, $40 \%$ at 9:00 a.m. and $60 \%$ at 6:00 p.m. The calculations of feeding strategies and food conversion were adapted from OSTRENSKY and BARBIERI (2002).

In each production cycle, the weight gain was evaluated weekly by sampling 25 individuals per tank (PU). At the end of the experiment we obtained: final average weight $(\mathrm{g})$, productivity $\left(\mathrm{g} \mathrm{m}^{-2}\right)$, growth (g week $\left.{ }^{-1}\right)$, survival (relative) and feed conversion factor $(\mathrm{FCF})$.

The relationship between total length $(\mathrm{Lt})$ and total weight $(\mathrm{Wt})$ was described according to the power function $\mathrm{Wt}=\mathrm{aLt}$ ", where "a" and " $\mathrm{b}$ " are the regression parameters. The angular coefficient " $b$ " was tested for isometry using the $t$ test based on function $t$ $=(b-3) /$ Standard Error (ZAR, 2010). If "b" does not present a significant difference from 3 , the growth is isometric, and if it is higher or lower, it is positive or negative allometric.

Growth parameters were obtained for both species using the von Bertalanffy equation - based on data of length $(\mathrm{mm})$ and age (weeks): $\mathrm{L}_{\mathrm{i}}=\mathrm{L} \infty\left[1-\mathrm{e}^{-\mathrm{k}(\mathrm{t}-}\right.$ $\left.\begin{array}{c}\mathrm{t} \\ 0\end{array}\right]$, where: $\mathrm{Li}=$ length of an individual at age $\mathrm{i} ; \mathrm{L} \infty=$ asymptotic length; $\mathrm{k}=$ growth coefficient; $\mathrm{t}_{0}=$ age (in weeks) of the individual when $\mathrm{L}_{\mathrm{i}}=0$.

To evaluate the growth difference between species, the equation parameters were compared by the maximum likelihood ratio (KIMURA, 1980). The relationships and equations were adjusted according to the non-linear least-square method using the "nls" function of the "stats" package, and the determination coefficients $\left(\mathrm{R}^{2}\right)$ using the function "Rsq" of the "qpcR" package, both in the R environment ( $\mathrm{R}$ CORE TEAM, 2013).

\section{ResULTS}

The average temperature was kept at $24.5 \pm 0.5^{\circ} \mathrm{C}$, controlled by thermostats, throughout the experiments. The salinity was $32.5 \pm 0.5 \mathrm{~g} \mathrm{~L}^{-1}$ and the parameters of $\mathrm{pH}$, ammonia, nitrite and nitrate did not differ significantly between the PUs or the experiments $\quad(P<0.05)$, being within the acceptable range for these species (WASIELESKY et al., 1994; BRITO et al., 2000; BARBIERI, 2010).

The shrimp were harvested after 120 days. The cultivation parameters are shown in Table 1. The length-weight relationships, the values of determination coefficients $\left(\mathrm{R}^{2}\right)$, and the corresponding equations for $L$. schmitti and $F$. paulensis are given in Figure 2.

The relationships and coefficients were well adjusted to the model, with a determination coefficient of 0.982 for $L$. schmitti and 0.943 for $F$. paulensis. The angular coefficient (b) indicated negative allometric growth $\left(\mathrm{p}=4,314 \times 10^{-18}\right)$ for L. schmitti and isometric growth $(\mathrm{p}=0.267)$ for $F$. paulensis.

Table 1. Mean ( \pm standard deviation) of production parameters of L. schmitti and F. paulensis cultivated for 120 days in water recirculation system.

\begin{tabular}{lll}
\hline \hline Variables & L. schmitti & F. paulensis \\
\hline Final weight $(\mathrm{g})$ & $3.99 \pm 0.69 \mathrm{a}$ & $4.05 \pm 0.41 \mathrm{a}$ \\
Yield $\left(\mathrm{g} \mathrm{m}^{-2}\right.$ cycle) & $830.98 \pm 49.86 \mathrm{a}$ & $844.03 \pm 32.89 \mathrm{a}$ \\
Growth $\left(\mathrm{g} \mathrm{week}^{-1}\right)$ & $0.22 \pm 0.08 \mathrm{a}$ & $0.21 \pm 0.14 \mathrm{a}$ \\
Survival $(\%)$ & $82.26 \pm 8.19 \mathrm{a}$ & $80.89 \pm 10.08 \mathrm{a}$ \\
FCF & $2.58 \pm 0.63 \mathrm{a}$ & $2.62 \pm 0.37 \mathrm{a}$ \\
\hline
\end{tabular}

Different letters (a, b) on different rows show significant differences in the Tukey test $(P<0.05)$. Different letters on the same row indicate significant differences. 

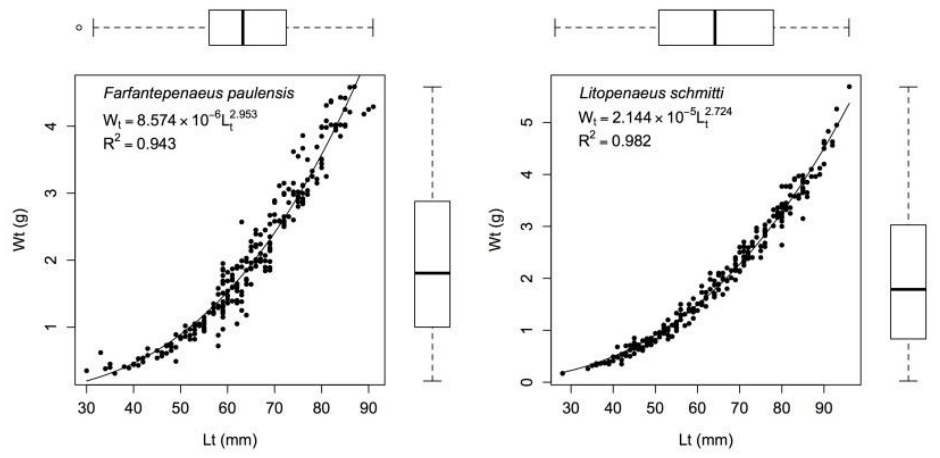

Fig. 2. Length-weight relationship of $F$. paulensis and $L$. schmitti cultivated in water recirculation system.

The von Bertalanffy growth model fitted to data on length in weeks with determination coefficients of 0.900 for L. schmitti and 0.841 for $F$. paulensis (Table 2). Fig. 3 shows the resulting curve model, adjusted to the data for total length as a time function (weeks) for both species.

Table 2. Parameters of von Bertalanffy growth equation for $L$. schmitti and $F$. paulensis based on total length.

\begin{tabular}{lllll}
\hline \hline Species & $\mathrm{L}_{\infty}(\mathrm{mm})$ & $\mathrm{k}$ & $\mathrm{t}_{0}$ & $\mathrm{R}^{2}$ \\
\hline L. schmitti & 172.66 & 0.027 & -8.158 & 0.900 \\
F.paulensis & 110.13 & 0.050 & -8.818 & 0.841 \\
\hline
\end{tabular}

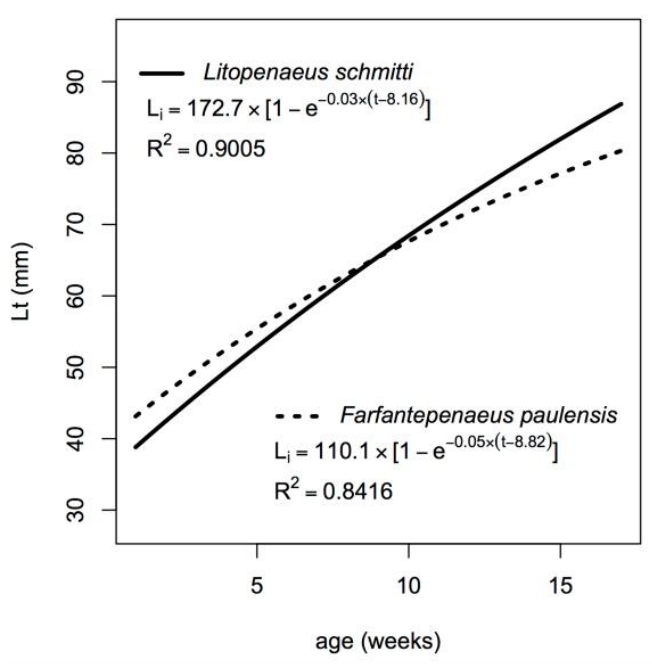

Fig. 3. Growth curves adjusted to the von Bertalanffy model for $L$. schmitti and $F$. paulensis cultivated in water recirculation system based on total length.

\section{DisCUSSION}

SOARES et al. (2005) and FRÓES et al. (2007) show that the commercial cultivation of $F$. paulensis depends on the development of production technologies of post larvae; there are also studies on nutritional features at different life stages. The same scenario applies to L. schmitti, though there is less information about its potential for farming in Brazil.

Estimates of growth curves (in length or weight) are the tools used in shrimp farming to compare the growth of the various species under the varying conditions of captivity or the natural environment (PEIXOTO et al., 2001). According to these latter authors, penaeid growth is influenced by both environmental and biological factors, as well as by the culture area and phase of the life cycle. For ALBERTONI et al. (2003), length-weight relationships are important to determine the conditions for a species' survival in different habitats, for providing the data for growth and production estimates, as well as for describing the structural characteristics of individuals in populations.

According to ARREGUÍN-SÁNCHEZ (1981), water temperature plays a key role in shrimp metabolism, changing its growth rate and affecting the speed of physiological processes. (2012) reared $L$. schmitti within a temperature range of $19.7-30.7^{\circ} \mathrm{C}$ and observed weight gain and individual growth at temperatures below $24^{\circ} \mathrm{C}$. KRUMMENAUER et al. (2006) reared $F$. paulensis in southern Brazil and observed a decrease in growth in the colder months of the year. OSTRENSKY and PESTANA (2000) found a 50\%reduction in growth rates at an average temperature of $18^{\circ} \mathrm{C}$ in the same species and location. $\mathrm{We}$, therefore, opted in the current study to maintain the temperature at $24.5^{\circ} \mathrm{C}$. The use of the recirculation system, in which all the abiotic parameters in 
production are controlled, enabled the authors to use the growth curves to assess the growth performance of L. schmitti and F. paulensis.

The feeding frequency of twice a day was considered ideal by OSTRENSKY and BARBIERI JR (2002). Although feeders were not used to reduce feed or natural food supplement loss, the frequency of consumption obtained - of between 2.58 and 2.62 was lower than that reported by MÁRQUEZ et al. (2012) of 3.58 to 4.43 , but similar to that of PRETO et al. (2009) and SOUZA et al. (2009), respectively, of 2.77 and 2.31 to 2.85 , thus demonstrating the efficiency of the water recirculation system.

In the system proposed, at 120 days of cultivation with 208 individuals per $\mathrm{m}^{2}$, the average weekly weight gain was $0.22 \mathrm{~g}$ for $L$. schmitti and 0.21 for $F$. paulensis, lower than that of between 0.55 and $0.36 \mathrm{~g}$, with average final weight of between 4.95 and $8.20 \mathrm{~g}$ obtained by MÁRQUEZ et al. (2012) for $L$. schimitti. OSTRENSKY and PESTANA (2000) obtained an average growth value of $0.73 \mathrm{~g} \mathrm{week}^{-1}$ for $F$. paulensis and $0.61 \mathrm{~g} \mathrm{week}^{-1}$ for $L$. schmitti with a density of 10 individuals per $\mathrm{m}^{2}$. FRAGA ET AL. (2002) reared L. schmitti for 10 weeks at a density of 10 individuals per $\mathrm{m}^{2}$ and obtained a final average weight of between 7.43 and $10.45 \mathrm{~g}$. SOUZA ET AL. (2009) reared $F$. subtilis with an initial average weight of $2.7 \mathrm{~g}$ for 12 weeks at a density of 16 individuals per $\mathrm{m}^{2}$ and obtained a weight gain of $0.45 \mathrm{~g} \mathrm{week}^{-1}$. It is possible to observe the effect of the higher density on the lower average final weight of $3.99 \mathrm{~g}$ and $4.05 \mathrm{~g}$ for $L$. schmitti and $F$. paulensis, respectively.

The average yield of $830.98 \mathrm{~g} \mathrm{~m}^{-2}$ for $L$. schmitti and $844.03 \mathrm{~g} \mathrm{~m}^{-2}$ for $F$. paulensis was higher than that obtained by FERNANDEZ et al. (1994) of $147-201 \mathrm{~m}^{-2}$ with a population density of between 18-50 individuals per $\mathrm{m}^{2}$, similar to the $46-234 \mathrm{~g}$ $\mathrm{m}^{-2}$ obtained by MÁRQUEZ et al. (2012) who studied densities of between 8-50 individuals per $\mathrm{m}^{2}$. The high density did not affect the final average survival rate that ranged from 80.89 to $82.26 \%$ for $F$. paulensis and L. schmitti, respectively; higher than the $47 \%$ obtained by OSTRENSKY and PESTANA (2000) for $F$. paulensis and $75 \%$ by FERNANDEZ et al. (1994) for L. schmitti, but similar to the best rates obtained by MÁRQUEZ et al. (2012) with 70-92\% for L. schmitti and SOUZA et al. (2009) with $61-91 \%$ for $F$. subtilis. In this present study, although the final average weight obtained is low, the high population density and survival rate promoted a better yield.

SOUZA ET AL. (2009) and MÁRQUEZ et al. (2012) also used a commercial feed for $L$. vannamei, the only one available for peneids on the Brazilian market. For SOUZA et al. (2009), the feeding rate (\% of biomass) used ranged from $8-2 \%$ and for MARQUEZ et al. (2012), from 50-3\%. In this study, the rate was $3 \%$. This high variation in feed rate is reflected directly in the final weight of the farmed animals; however, given that the objective of this study was the analysis of shrimp growth for use as live bait, the weight gain of individuals was not taken into account, only the size achieved by individuals, similar to that used for sporting fishing.

PEIXOTO et al. (2003) reared juveniles of $F$. paulensis in southern Brazil at temperatures of between 19 and $30^{\circ} \mathrm{C}$ and considered using the length-weight relationship and the $b$ coefficient of 2.54, indicating negative allometric growth, lower than that obtained in the current study for the same species, where b was 2.95 , characterizing isometric growth. This difference in growth may be a reflection of temperature oscillation during cultivation.

For other species of the genus, different growth patterns were observed, being positive allometric for $F$. duorarum, $F$. subtilis, $F$. aztecus, $F$. notialis and females of $F$. brasiliensis, and negative allometric for males of $F$. brasiliensis (PÉREZCASTAÑEDA; DEFEO, 2002; LEITE Jr; PETRERE Jr, 2006; CORRÊA; MARTINELLI, 2009).

Shrimp of the Farfantepenaeus genus tend to gain more weight than from the Litopenaeus genus, indicating greater potential zootechnical yield under ideal conditions of culture. When shrimp are used as live bait, weight gain is secondary and length the main factor, showing that both species have potential for this market.

According to PAULY et al. (1984), the annual growth rate of penaeids can range from 0.25 to $2.5 \mathrm{~mm} /$ year $^{-1}$, their longevity being of between 1.5 and 2.5 years. In this study, the estimated growth rate values were 1.29 for $L$. schmitti and 2.4 for $F$. paulensis, thus remaining within the range mentioned.

Using fisheries data, PASQUIER and PEREZ (2007) obtained estimates for $\mathrm{k}$ and $\mathrm{L} \infty$ for L. schmitti very similar to those obtained in this study, as well as to those obtained by ARREGUÍNSANCHEZ (1993) and VILLEGAS and BARQUERO (2000) for other species of the same genus (Table 3). On the other hand, there are differences between the estimates of LOPEZMARTINEZ et al. (2005) for L. stylirostris and Chávez (1973) for L. vannamei.

The estimates obtained in this study for F. paulensis were similar to those of MELLO (1973) and ARREGUÍN-SÁNCHEZ (1981), but differed from those for other species of the same genus. An annual growth rate higher than that obtained in this study is reflected in a lower Lo (Table 3), although these species grow considerably in nature. 
Table 3. Comparison of growth parameters obtained in this study with those reported in the literature.

\begin{tabular}{|c|c|c|c|c|}
\hline Species & k $\left(\right.$ year $\left.^{-1}\right)$ & $\mathrm{L} \infty$ & $t_{0}$ & References \\
\hline L. schmitti & $1.30^{*}$ & 173 & $-0.169^{*}$ & Present study \\
\hline L. schmitti & 1.81 & 173 & -0.032 & $\begin{array}{l}\text { Pasquier \& } \\
\text { Perez, } 2007\end{array}$ \\
\hline L. setiferus & 1.11 & 191 & -0.300 & $\begin{array}{l}\text { Arreguín- } \\
\text { Sanchéz ,1993 }\end{array}$ \\
\hline L. stylirostris & 2.04 & 244 & -0.080 & $\begin{array}{l}\text { Lopez- } \\
\text { Martinez et al., } \\
2005\end{array}$ \\
\hline L. vannamei & 5.16 & 188 & -0.205 & Chávez 1973 \\
\hline L. occidentalis & 1.40 & 190 & - & $\begin{array}{l}\text { Villegas } \\
\& \text { Barquero, } \\
2000\end{array}$ \\
\hline F. paulensis & $2.4^{*}$ & 110 & $-0.183^{*}$ & Present study \\
\hline F. brasiliensis & 1.24 & 290 & - & $\begin{array}{l}\text { Leite Jr \& } \\
\text { Petrere Jr, } \\
2006\end{array}$ \\
\hline F. paulensis & 1.34 & 275 & - & $\begin{array}{l}\text { Leite Jr \& } \\
\text { Petrere Jr, } \\
2006\end{array}$ \\
\hline F. subtilis & 1.11 & 201 & - & $\begin{array}{l}\text { Isaac et al., } \\
1992\end{array}$ \\
\hline F. aztecus & 4.02 & 169 & - & Parrack, 1979 \\
\hline F. duorarum & 3.40 & 192 & 0.680 & Kutkuhn, 1966 \\
\hline F. notialis & 1.55 & 131 & - & Nwosu, 2009 \\
\hline
\end{tabular}

The L. schmitti and F. paulensis shrimp species may, in the mid and long term, replace the exotic species L. vannamei in Brazil, contributing to the sustainability of the activity, reducing the impact caused by the culture of an exotic species, thus generating direct and indirect jobs for this production chain.

Some authors consider the penaeid shrimp culture as offering comparatively better financial returns for many coastal fishing communities in southeastern and southern Brazil (CAVALLI et al., 2008; PRETO ET AL., 2009).

The reintroduction of the native shrimp species L. schmitti and $F$. paulensis into Brazilian shrimp farming is directly and intrinsically related to the undertaking of research and study that generate scientific knowledge and encourage the culture of these shrimp species. On the coast of São Paulo State, in southeastern Brazil, there are almost no areas for shrimp farming in large ponds due to the coast's geomorphology and the numerous real estate ventures located along it, which makes the water recirculation system a possible solution, from both the technical and economic points of view, for the shrimp production sector.

The use of L. schmitti and $F$. paulensis as live bait to attend the demands of the recreational fishery market opens up a business opportunity for small producers offering a product of high value, because shrimps are traded by unit at attractive prices.

\section{ACKNOWLEDGMENTS}

The authors would like to thank the FAPESP (Proc: 2011/50632-8) for their financial support.

\section{REFERENCES}

ADAMS, C. M.; GRIFFIN, W. L.; NICHOLS, J. P.; BRICK, R. E. Application of a bio-economic-engineering model for shrimp mariculture systems. Southern J. Agr. Econ., v. 2, p.135-141, 1980.

ALBERTONI, E.; PALMA-SILVA, C.; ESTEVES, F. A. Crescimento e fator de condição de Farfantepenaeus brasiliensis (Latreille) e $F$. paulensis (Pérez-Farfante) (Crustacea, Decapoda, Penaeidae) em uma lagoa costeira tropical do Rio de Janeiro, Brasil. Rev. Bras. Zool., v. 20, p. 409-418, 2003.

ANAND, P. S. S.; KOHLI, M. P. S.; ROY, S. D.; SUNDARAY, J. K.; SINHA, A.; PAILAN, G. H.; SUKHAM, M. K. Effect of dietary supplementation of periphyton on growth performance and digestive enzyme activities in Penaeus monodon. Aquaculture, v. 392, p. 59-68, 2013.

ARREGUÍN-SANCHÉZ, F. Tasa de crecimiento del camaron rojo (Penaeus brasiliensis Latreille 1817) de las costas de Quintana Roo, México. Cienc. Pesq., v. 1, p. 61-70, 1981.

ARREGUÍN-SANCHÉZ, F. Age and growth estimation for the White Shrimp, Penaeus setiferus, from the offshore fishery of the Northwestern Gulf of Mexico. In: PROCEEDINGS OF THE 45TH ANNUAL SESSION GULF AND CARIBBEAN FISHERIES INSTITUTE, v. 45, p. 95-127, Mérida, Yucátan: Gulf and Caribbean Fisheries Institute, Inc., 1994.

BARBIERI, E. Acute toxicity of ammonia in white shrimp (Litopenaeus schmitti) (Burkenroad, 1936, Crustacea) at different salinity levels. Aquaculture, v. 306, p. 329$333,2010$.

BARROS, L.C.; BARRETO, O.J.S; HENRIQUES, M.B. The economic viability for the production of live baits of White Shrimp (Litopenaeus schmitti) in recirculation culture system. Aquacult. Int., DOI 10.1007/s10499014-9792-4, 2014.

BRITO, R.; CHIMAL, M. E.; ROSAS, C. Effect of salinity in survival, growth, and osmotic capacity of early juveniles of Farfantepenaeus brasiliensis (decapoda: penaeidae). J. Exp. Mar. Biol. Ecol., v. 244, p. 253263, 2000.

CAVALLI, R. O.; LEHNEN, T. C.; KAMIMURA, M. T.; WASIELESKY, W. F. B. Desempenho de pós-larvas do camarão-rosa Farfantepenaeus paulensis alimentadas com diferentes frequências durante a fase de berçário. Acta Sci Biol Sci, v. 30, p. 231-236, 2008.

CHÁVEZ, E. Estudio sobre la tasa de crecimiento del camarón blanco (Penaeus vannamei, Boone) de la región sur del Golfo de California. Ciencia, v. 28, p.79-85, 1973.

CORRÊA, A. B.; MARTINELli, J. M. Composição da População do Camarão Rosa Farfantepenaeus subtilis (Pérez-Farfante 1967) no Estuário do Rio Curuçá, Pará, Brasil. Ver. Cient. UFPA, v. 7, p. 1-18, 2009. 
DAVIS, D. A.; ARNOLD, C. R. The design, management and production of a recirculating raceway system for the production of marine shrimp. Aquacult. Eng., v. 17, p. 193-211, 1998

FERNANDEZ, R., BARBARO, J.; SOSA, R. Engorde intensivo del camaron Penaeus schmitti en Santa Cruz del Sur, Cuba. Re.v Invest. Mar., Havana, v. 15, p. 157$163,1994$.

FÓES, G. K.; FRÓES, C.; KRUMMENAUER, D.; POERSCH, L.; WASIELESKY, W. Nursery of pink shrimp Farfantepenaeus paulensis in biofloc technology culture system: survival and growth at different stocking densities. J. Shellfish Res., v. 30, p. 367-373, 2011.

FRAGA, I.; GALINDO, J.; ARAZOZA, M.; SANCHEZ, A.; JAIME, B.; ALVARES, S. Evaluación de niveles de proteína y densidades de siembra en el crecimiento del camarón blanco Litopenaeus schmitti. Rev. Inv. Mar., Havana, v. 23, p. 141-147, 2002.

FRÓES, C. N.; ABE, M. P.; WASIELESKY, W. J.; PRENTICE, C.; CAVALLI, R. O. 2007. Efeito de dietas práticas com diferentes níveis de proteína bruta na sobrevivência e crescimento do camarão-rosa Farfantepenaeus paulensis (Pérez-Farfante 1967). Atlântica, v. 29, p. 25-34, 2007.

GODDARD, S. Feed Management in Intensive Aquaculture. Chapman \& Hall, New Jersey. 189 p., 1996.

ISAAC, V. J.; DIAS-NETO, J.; DAMASCENO, F. G. Biologia, dinâmica de populações e administração pesqueira do camarão Penaeus subtilis da região norte do Brasil. Brasília: IBAMA, 187 p. (Coleção Meio ambiente, Série Estudos Pesca), 1992.

KIMURA, D. K. Likelihood methods for the von Bertalanffy growth curve. Fish. Bull., v. 77, p. 765-776, 1980.

KNEIB, R. T.; HUGGLER, M. C. Tag Placement, mark retention, survival and growth of juvenile white shrimp (Litopenaeus setiferus Pérez-Farfante 1969) injected with coded wire tags. J. Exp. Mar. Biol. Ecol., v. 266, p.109120, 2001.

KRUMMENAUER, D.; WASIELESKY, W. J.; CAVALLI, R. O.; PEIXOTO, S.; ZOGBI, P. R. Viabilidade do cultivo do camarão-rosa Farfantepenaeus paulensis (Crustacea:Decapoda) em gaiolas sob diferentes densidades durante o outono no sul do Brasil. Ciência Rural, Santa Maria, v. 36, p. 252-257, 2006.

KUTKUHN, J. H. Dynamics of a Penaeid shrimp population and management implications. Fish. Bull., v. 65, p. 313$338,1966$.

LEITE JR, N. O.; PETRERE JR, M. Growth and mortalities of the pink-shrimp Farfantepenaeus brasiliensis Latreille 1970 and F. paulensis Pérez-Farfante 1967 in Southeast Brazil. Braz. J. Biol., v. 66, p. 523-536, 2006.

LOMBARDI, J. V.; MARQUES, H. L. A.; BARRETO, O. J. $S$. Floating cages in open seawater: an alternative for promoting integrated aquaculture in Brazil. World Aquac., v. 32, p. 47-50, 2001.

LÓPEZ-MARTÍNEZ, J.; RÁBAGO-QUIROZA, C.; NEVÁREZ-MARTÍNEZ, M. O.; GARCIA-JUAREZ, A. R.; RIVERA-PARRA, G.; CHÁVEZ-VILLALBA, J. Growth, reproduction, and size at first maturity of blue shrimp, Litopenaeus stylirostris (Stimpson 1874) along the east coast of the Gulf of California, Mexico. Fish. Res., v. 71, p. 93-102, 2005.
MÁRQUEZ, J. E. Q.; ANDREATTA, E. R.; VINATEA, L.; OLIVEIRA, A.; BRITO, L. O. Efeito da densidade de estocagem nos parâmetros zootécnicos da criação de camarões Litopenaeus schmitti. Bol. Inst. Pesca, v. 38, p. 145-153, 2012.

MELLO, J. T. C. Estudo populacional do camarão "rosa", Penaeus brasiliensis, (Latreille 1817) e Penaeus paulensis (Perez-Farfante 1967). Bol. Inst. Pesca, v. 2 , p. 19-65, 1973.

NWOSU, F. M. Population Dynamics of the Exploited Penaeid Shrimp, Penaeus (Farfantepenaeus notialis) in the Cross River Estuary, Nigeria. J. Fish. Int., v. 4, p. 62-67, 2009.

OSTRENSKY, A.; BARBIERI JR, R. C. Camarões marinhos II - Engorda. Aprenda Fácil Editora, Viçosa, 2002.

OSTRENSKY, A.; PESTANA, D. Avaliação das taxas de crescimento de Farfantepenaeus paulensis PérezFarfante, 1967 em viveiros de cultivo. Arch. Vet. Sc., v. 5, p. 5-15, 2000.

PARRACK, M. L. Aspects of brown shrimp, Penaeus aztecus, growth in the Northern Gulf of Mexico. Fish. Bull., v. 76, p. 827-836, 1979.

PASQUIER, G. A.; PEREZ, E. P. Age and growth of the white shrimp Litopenaeus schmitti in Western Venezuela. Interciência, v. 29, p. 212-218, 2004.

PASQUIER, G. A.; PEREZ, E. P. Comparación de métodos de estimación de parâmetros de crecimento del camarón blanco Litopenaeus schmitti em el occidente de Venezuela. Interciência, v. 32, p. 41-47, 2007.

PAULY, D.; INGLES, J.; NEAL, R. Application to shrimp stocks of objective methods for the estimation of growth, mortality and recruitment - related parameters from length-frequency data (ELEFAN I and II). In: GULLAND J, ROTHSCHILD B (Eds.), Penaeid Shrimp, Their Biology and Management. New Books, Great Britain, pp. 220-234, 1984.

PEIXOTO, S.; D'INCAO, F.; WASIELESKY, W. J. Application of von Bertalanffy growth curves in Farfantepenaeus paulensis (Decapoda, Penaeidae) captive broodstock. Nauplius, v. 9, p. 149-155, 2001.

PEIXOTO, S.; WASIELESKY, W. J.; LOUZADA, L. Comparative Analysis of Pink Shrimp, Farfantepenaeus paulensis, and Pacific White Shrimp, Litopenaeus vannamei, Culture in Extreme Southern Brazil. J. Appl. Aquac., v. 14, p. 101-111, 2003.

PÉREZ-CASTAÑEDA, R.; DEFEO, O. Morphometric relationships of penaeid shrimps in a coastal lagoon: spatio-temporal variability and management implications. Estuaries, v. 25, p. 282-287, 2002.

PRETO, A. L.; PISSETTI, T. L.; WASIELESKY, W. J.; PORSCH, L. H.; CAVALlI, R. O. Production of live bait-shrimp (Farfantepenaeus paulensis) in cages at varying stocking densities. Bol. Inst. Pesca, v. 35, p. 3945, 2009.

R CORE TEAM : A language and environment for statistical computing. R Foundation for Statistical Computing, Vienna. URL http://www.R-project.org/,2013.

SOARES, R. B.; PEIXOTO, S.; WASIELESKY, W. J.; D'INCAO, F. Feeding rhythms and diet of Farfantepenaeus paulensis under pen culture in Patos Lagoon estuary, Brazil. J. Exp. Mar. Biol. Ecol., v. 322, p. 167-176, 2005. 
SOUZA, F. M. M.; MESSIAS, G. A.; FIALHO, D. H. F.; SOARES, R. B.; CORREIA, E. S. Crescimento do camarão marinho Farfantepenaeus subtilis (PérezFarfante, 1967) cultivado em tanques com diferentes protocolos de fertilização orgânica Acta Scient. Biol. Sci., v. 31, p. 221-226, 2009.

TIAN, X.; LEUNG, P.; HOCHMAN, E. Shrimp Growth Functions and Their Economic Implications. Aquac. Eng., v. 12, p. 81-96, 1993.

VALENTINI, H.; D'INCAO, F.; RODRIGUES, L. F.; REBELO-NETO, J. E.; RAHN, E. Análise da pesca do Camarão-rosa (Penaeus brasiliensis e Penaeus paulensis) nas regiões sudeste e sul do Brasil. Atlântica, v. 13, p. 143-157, 1991.

VILLEGAS, J. P.; BARQUERO, M. V. Length at first maturity, reproductive cycle and growth of the white shrimp (Penaeus occidentalis, Decapoda, Penaeidae) in the inner part of the Nicoya Gulf Costa Rica. Uniciencia, v. 17, p. 13-19, 2000.
WASIELESKY, W. J.; MARCHIORI, M. A.; SANTOS, M. H. S. Efeito da amônia no crescimento de pós-larvas do camarão rosa, Penaeus paulensis, Pérez- Farfante 1967 (Decapoda:Penaeidae). Nauplius, v. 2, p. 99-105, 1994.

WASIELESKY W. J.; PEIXOTO, S.; JENSEN, L.; POERSCH, L. H.; BIANCHINI, A. Estudo preliminar do cultivo do camarão-rosa Farfantepenaeus paulensis em cercados no estuário da Lagoa dos Patos. Bol. Inst. Pesca, v. 30, p. 63-70, 2004.

WYBAN, J. A.; SWEENEY, J. N.; KANNA, R. A. Shrimp Yields and Economic Potential of Intensive Round Pond Systems. J. World Aquac. Soc., v.19, n. 4, p. 210-217, 1988.

ZAR, J. H. Biostatistical Analysis. 5th Edition. Pearson Prentice-Hall, Upper Saddle River, New Jersey, 2010.

(Manuscript received 27 February 2014; revised 07 September 2014; accepted 09 September 2014) 